\title{
Administrative Organization of Columbia University Libraries
}

\author{
BY RICHARD H. LOGSDON
}

ThE Two CHARTs that accompany this note describe the present administrative organization of the Columbia University libraries. The charts - the second is a detail of the first-are in large part self-explanatory, but a few comments are necessary.

The format was chosen largely for ease of graphic display, but it is not without some symbolism. The six units ranged around the outside of the square in Chart 1 are the major public service divisions of the Columbia library system. The sciences are on the right side; what might be called the applied social sciences are on the left; and the libraries supporting humanistic and historical studies are oriented towards the base.

The technical and administrative service units inside the square are in direct line communication with any or all of the public service divisions. An alternative and direct line between both the office of the assistant director and the coordinating committees and the office of the director of libraries is provided to reflect the fact that both are in some matters "deputies" of the director.

The nature of the coordinating committees requires some explanation since they are a recent innovation. The increased size and attendant complexity of the university libraries, stemming in large part from the growth of the university itself, have made regular and productive meetings involving all of the senior library officers essential. To focus the attention of this group on specific subjects, three coordinating committees have been established, one for each of
Dr. Logsdon is Director of Libraries, Columbia University.

the major segments of internal library activity - that is, development and maintenance of the collections, bibliographic control, and operations planning and review. The seven division heads and the assistant and associate directors constitute the membership of each committee. The director of libraries is also normally a participant at the meetings. It is anticipated that these committees will evolve in such a way that they will make significant contributions to library administration by accelerating the factfinding process that must precede policy formation, and by stimulating coordinated and consistent implementation of policy once it is established. For the first year the coordinator of cataloging, the Butler librarian, and the associate director of libraries have been designated chairmen of the committees on bibliographic control, collection development, and operations, respectively. Each committee meets monthly, guided by a planned agenda and working papers. Other members of the staff of the library may be asked to assist in the work of a particular committee as appropriate to the topic under study. Staff and clerical assistance for the committees is provided by the office of the director, including assignment of the time of a research assistant. The result of the work of a committee on any agenda item is normally a statement or a report incorporating the suggestions or recommendations of the 


\section{CHART 1}

COLUMBIA UNIVERSITY LIBRARIES

THE PRINCIPAL COMPONENTS OF THE LIBRARY SYSTEM

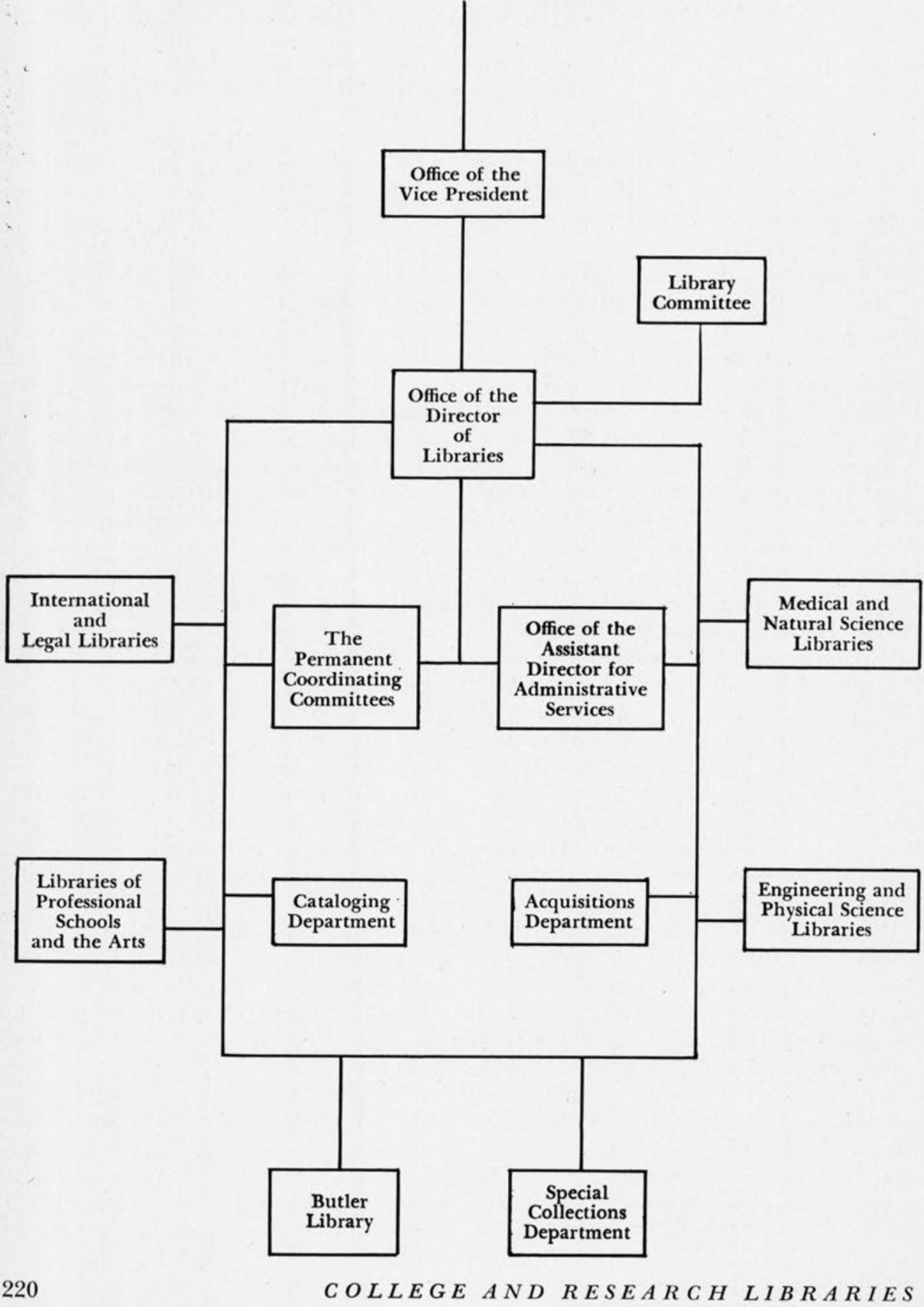




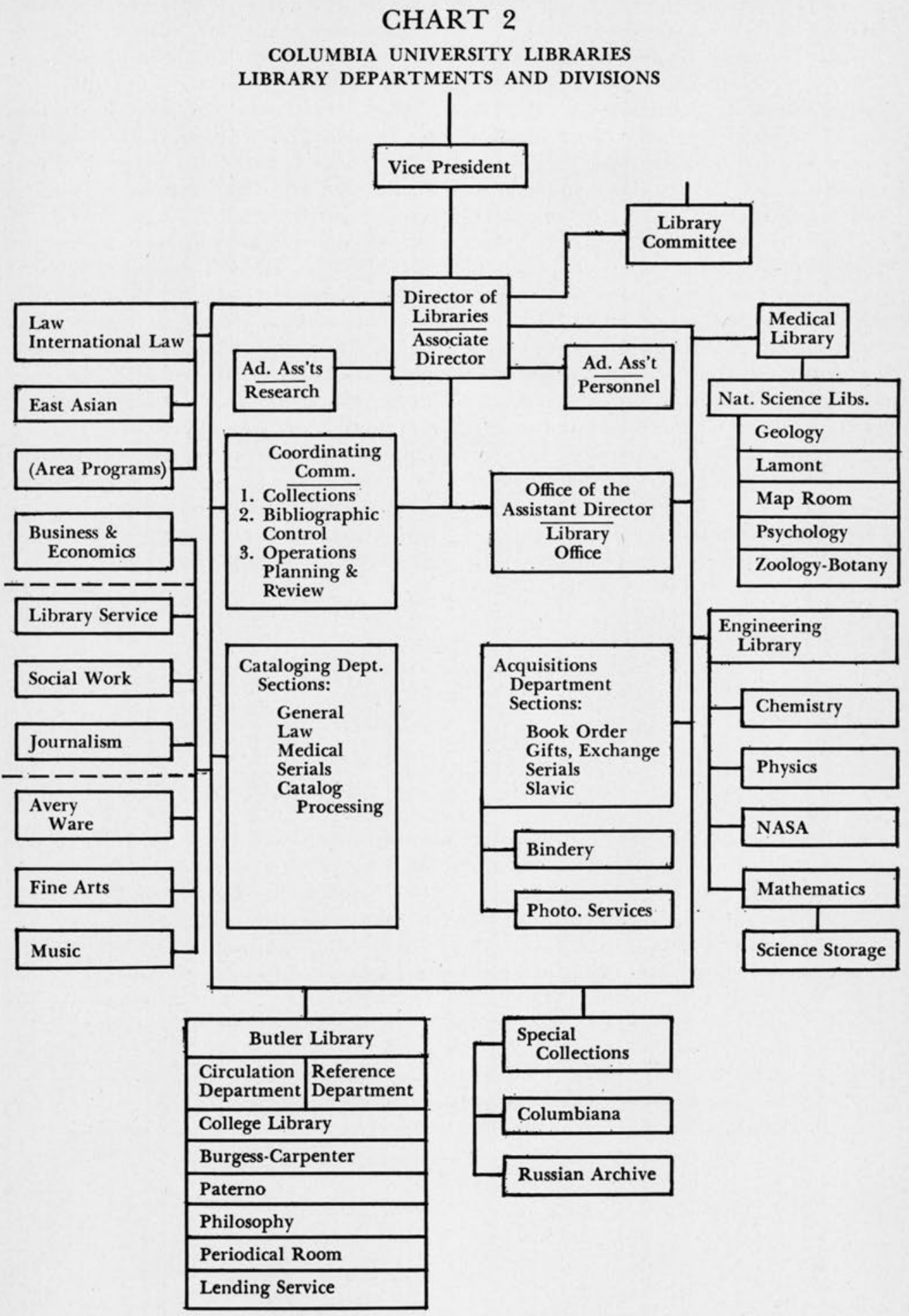


members to the director of libraries for decision or other necessary action.

Little comment seems necessary about Chart 2, which identifies all departments and sections in the library system. It should be noted that there is no division head for the libraries serving professional schools and the arts, this responsibility now being carried in part by the assistant director and in part by the Butler librarian. At the moment, the head of the business and economics library reports to the associate director. Finally, it is noted that NASA is a library operated on contract for the National Aeronautics and Space Administration. Although not formally a part of the Columbia system, there is substantial interplay between this unit and the others in the engineering and physical sciences division.

Persons interested in the evolution of Columbia's plan of organization of library resources and services are referred to The University Library by Louis $\mathrm{R}$. Wilson and Maurice F. Tauber (2d edition, New York; Columbia University Press, 1956, p. 137-38); The Columbia University Libraries (Maurice F. Tauber, C. Donald Cook, Richard H. Logsdon. New York: Columbia University Press, 1958), and the brief report in College and Research Libraries, XV (1954), 15860 , "Changes in Organization at Columbia,” by Richard H. Logsdon.

One statement made in 1953 , the date of the last major change in organization, is equally true today. There is no one perfect organization for all time, but rather a choice is always necessary among the more promising alternatives at a given time. No feature of the organization and way of operating should be considered as fixed. If something fails to work out in practice, a change should be made quickly to something better.

\section{Library Buildings Preconference Plans}

A PRECONFERENCE Library Buildings Institute will be held July 12-13, prior to the opening of the ALA annual conference in Chicago, July 14-20. The theme for the institute will be "Library Buildings for Quality Service," and the institute will consist of a general session devoted to the problems of the library building consultant, and four periods of individual sessions by types of libraries: college and university, public, school, and institutional. Registration fees of $\$ 16.00$ should be sent, in advance, to the LAD office at ALA headquarters, 50 E. Huron St., Chicago 11, Ill.

The LAD Buildings Committee for College and University Libraries at its four sessions will consider the building plans of eight libraries, two in each of the four categories: junior colleges, universities, colleges, and professional school libraries. 